\title{
ANALYSIS AND DESIGN OF USER INTERFACE/USER EXPERIENCE WITH THE DESIGN THINKING METHOD IN THE ACADEMIC INFORMATION SYSTEM OF JENDERAL SOEDIRMAN UNIVERSITY
}

\author{
Hananda Ilham $^{* 1}$, Bangun Wijayanto ${ }^{2}$, Swahesti Puspita Rahayu ${ }^{3}$ \\ 1,2,3 Informatika, Fakultas Teknik, Universitas Jenderal Soedirman \\ Email: ${ }^{1}$ hananda.zuhdi@mhs.unsoed.ac.id, ${ }^{2}$ bangun.wijayanto@unsoed.ac.id, ${ }^{3}$ swahesti.rahayu@ unsoed.ac.id
}

(Naskah masuk: 23 Oktober 2020, diterima untuk diterbitkan: 28 Desember 2020)

\begin{abstract}
User Interface/User Experience (UI/UX) design is very important because with a good design that meets user needs, it can make users feel comfortable when using a product. One example is the Academic Information System (SIA), if the design of the SIA is not user friendly, it will have an impact on both the user and the system. Such as input errors, missing information, difficulties in using it. The purpose of conducting UI / UX analysis and design at SIA Universitas Jenderal Soedirman is to solve the problems experienced by users today. Users involved in this research are students. Design is made using the Design Thinking method and for the testing using Usability Testing.
\end{abstract}

Keywords: academic information system, design thinking, UI/UX.

\section{ANALISIS DAN PERANCANGAN USER INTERFACE/USER EXPERIENCE DENGAN METODE DESIGN THINKING PADA SISTEM INFORMASI AKADEMIK UNIVERSITAS JENDERAL SOEDIRMAN}

\begin{abstract}
Abstrak
Desain User Interface/User Experience (UI/UX) merupakan hal yang sangat penting, karena dengan desain yang baik dan memenuhi kebutuhan pengguna, mampu membuat pengguna merasa nyaman saat menggunakan suatu produk. Salah satu contohnya adalah pada Sistem Informasi Akademik (SIA), jika desain dari SIA tersebut kurang ramah pengguna, akan berdampak kepada pengguna itu sendiri dan juga sistemnya. Seperti kesalahan input, informasi yang terlewat, kesusahan dalam menggunakannya. Tujuan dilakukannya analisis dan perancangan UI/UX pada SIA Universitas Jenderal Soedirman adalah untuk mengatasi permasalahan yang dialami pengguna saat ini. Pengguna yang terlibat pada penelitian ini yaitu mahasiswa. Perancangan yang dibuat menggunakan metode Design Thinking dan pengujian menggunakan Usability Testing.
\end{abstract}

Keywords: design thinking, sistem informasi akademik, UI/UX.

\section{PENDAHULUAN}

Universitas Jenderal Soedirman (UNSOED) merupakan perguruan tinggi negeri di Purwokerto yang berdiri pada tahun 1963 dan telah menggunakan sistem informasi. Salah satu layanan teknologi sistem informasi yang kurang tepat adalah pada pengelolaan akademik berupa Sistem Informasi Akademik Universitas Jenderal Soedirman (SIA UNSOED). SIA merupakan aplikasi berbasis web yang digunakan oleh dosen, tenaga kerja akademik dan mahasiswa baik S1 maupun S2 yang memberikan informasi seputar akadamik. Dengan adanya SIA ini, mahasiswa dapat mengetahui informasi akademik seperti jadwal mata kuliah, artikel ilmiah mahasiswa, Kartu Rencana Studi (KRS), Kartu Hasil Studi (KHS), serta hingga presensi mahasiswa.
Aplikasi SIA ini memiliki alamat http://akademik.unsoed.ac.id, dengan total artikel ilmiah 23.582 pada tanggal 23 September 2019 serta jumlah mahasiswa sebanyak 19.544 dan dosen 1.192 menurut data pelaporan 2019/2020 Ristekdikti. Dalam penelitian ini, telah digunakan sistem SIA sekitar 3 tahun lebih dan juga telah dilakukan observasi pengguna lain mengenai pendapat saat memakainya yang kebanyakan mengalami kesusahan. Dengan data sebanyak ini serta hasil observasi yang telah dilakukan, sistem informasi akademik haruslah memiliki UI (User Interface) dan UX (User Experience) yang baik untuk pengguna agar tidak kesusahan saat melakukan kegiatan didalam situs tersebut. 
Salah satu cara untuk mendapatkan UI/UX yang baik adalah dengan menggunakan metode design thinking karena metode ini berfokus pada pengguna atau user yang dipopulerkan oleh David Kelley dan Tim Brown. Metode ini bisa berfokus pada pengguna karena memiliki empat elemen yaitu: People Centered berarti berdasarkan pengguna, Highly Creative berarti dapat menggunakan kreativitas sebebas-bebasnya, Hands On berarti melakukan percobaan langsung tidak hanya teori, dan Iterative berarti proses yang dilakukan berulang kali untuk berimprovisasi [1].

Dilihat dari penelitian sebelumnya, dengan menggunakan design thinking mampu menjawab permasalahan serta tantangan yang dihadapi seperti membuat mudah dalam penggunaan serta pengalaman yang diberikan lebih baik. Berdasarkan permasalahan di atas maka pada penelitian ini dibuat Desain UI/UX SIA UNSOED dengan Metode Design Thinking yang dapat menjawab permasalahan dalam melakukan kegiatan didalam SIA.

\section{METODE PENELITIAN}

Metode Design Thinking merupakan pendekatan yang berpusat pada manusia terhadap inovasi yang dibentuk seperti keperluan desainer untuk mengintegrasikan kebutuhan orang-orang, teknologi dan kebutuhan bisnis. Dalam prosesnya, metode ini menggunakan pendekatan berdasarkan pengguna yang ditujukan untuk dapat memahami kebutuhan serta permasalahan pengguna [2].

Pada penelitian ini digunakan metode Design Thinking yang terdiri dari 5 tahapan yaitu Empathize, Define, Ideate, Prototype dan Test. Berikut gambaran dari beberapa langkah dalam Design Thinking [3]:

\section{Empathize}

Empati merupakan cara kita untuk memahami dan berbagi perasaan yang sama dengan yang dirasakan orang lain. Dengan rasa empati, kita mampu merasakan perasaan mereka tentang masalah, keadaan atau situasi [4]. Cara agar kita dapat berempati adalah dengan mengamati, mengikutsertakan pengguna, dan ikut coba mengalami apa yang dirasakan [5].

2. Define

Membuat list kebutuhan dan permasalahan yang dialami pengguna untuk dicari ide dan solusinya. Dalam proses ini kita dapat menggunakan beberapa teknik seperti Affinity Diagram, Points Of View, "How Might We" questions, tergantung dari kebutuhan kita [6].

\section{Ideate}

Tahap ini adalah tahap dimana motivasi dan kebutuhan pengguna diidentifikasi dan menghasilkan ide melalui brainstorming [7].

4. Prototype
Mengimplementasikan ide yang sudah didapat menjadi sebuah prototype atau produk yang dapat diuji coba [8].

5. Test

Pengujian dilakukan untuk mengetahui apakah sudah berjalan baik atau belum [9]. Prototype yang sudah jadi kemudian diuji kepada pengguna yang nantinya mendapatkan feedback untuk membuat produk lebih baik [10]. Dalam penelitian ini dilakukan pengujian kepada 5 orang karena ketika menguji kepada penguji ke-6 lebih, akan mendapatkan hasil yang mirip [11].

\section{HASIL DAN PEMBAHASAN}

Hasil penelitian menggunakan metode Design Thinking dilakukan sesuai dengan prosedur kerja sesuai dengan proses Design Thinking. Berikut pembahasannya:

\subsection{Empathize}

Dalam proses empathize ini, dilakukan observasi dan wawancara. Obervasi dilakukan melalui tingkah laku pengguna dalam menggunakan SIA dan keluhan. Kemudian untuk wawancara dilakukan dengan cara mengajukan pertanyaan kepada narasumber secara langsung untuk memperoleh data yang valid [12].

Setelah melakukan wawancara, kemudian membuat User-Perona dan Empathy Map untuk membantu dalam melihat pandangan dari pengguna. Empathy Map merupakan sebuah cara yang berpusat pada pengguna untuk memahami individu lain dengan melihat sudut pandang dari pengguna [13]. Sedangkan User-Persona merupakan karakter yang dibuat berdasarkan penelitian untuk mewakili jenis pengguna yang menggunakan produk [14].

Dari proses yang telah dilakukan, didapatkan pandangan pengguna mengenai SIA secara umum yaitu:

1. Pengguna lebih menggunakan laptop dalam mengurus administrasi dalam SIA.

2. Beberapa pengguna dalam melihat jadwal kuliahnya melihat pada website.

3. Kesusahan dalam mengakses dari handphone.

4. Desain yang tidak konsisten.

\subsection{Define}

Proses define merupakan proses mendapatkan pandangan user serta memahami kebutuhan pengguna. Pada tahap ini digunakan Affinity diagram dan dibuat information architecture.

Affinity Diagram merupakan metode yang dapat membantu mengumpulkan sejumlah besar data dan mengaturnya dalam kelompok atau tema berdasarkan hubungan mereka [15]. Gambar 1 merupakan bentuk dari affinity diagram pada penelitian ini. 
Dari data pada gambar 1, didapatkan permasalahan, kebutuhan dan hipotesis dari penelitian ini. Tabel 1 merupakan daftar kebutuhan pengguna yang telah didefinisikan.

Selanjutnya dibuat Information Architecture (IA) yang membantu pengguna dalam memahami lingkungan mereka dan menemukan apa yang mereka cari pada dunia nyata maupun online [16]. Dengan kata lain, IA ini merupakan penciptaan struktur informasi pada website,aplikasi dan lain-lainnya yang memungkinkan pengguna untuk memahami informasi karena ini adalah desain ulang sehingga hal ini membantu memperjelas arsitektur informasi dan menambahkan sedikit pada sistem. Gambar 2 merupakan hasil dari IA pada penelitian ini.
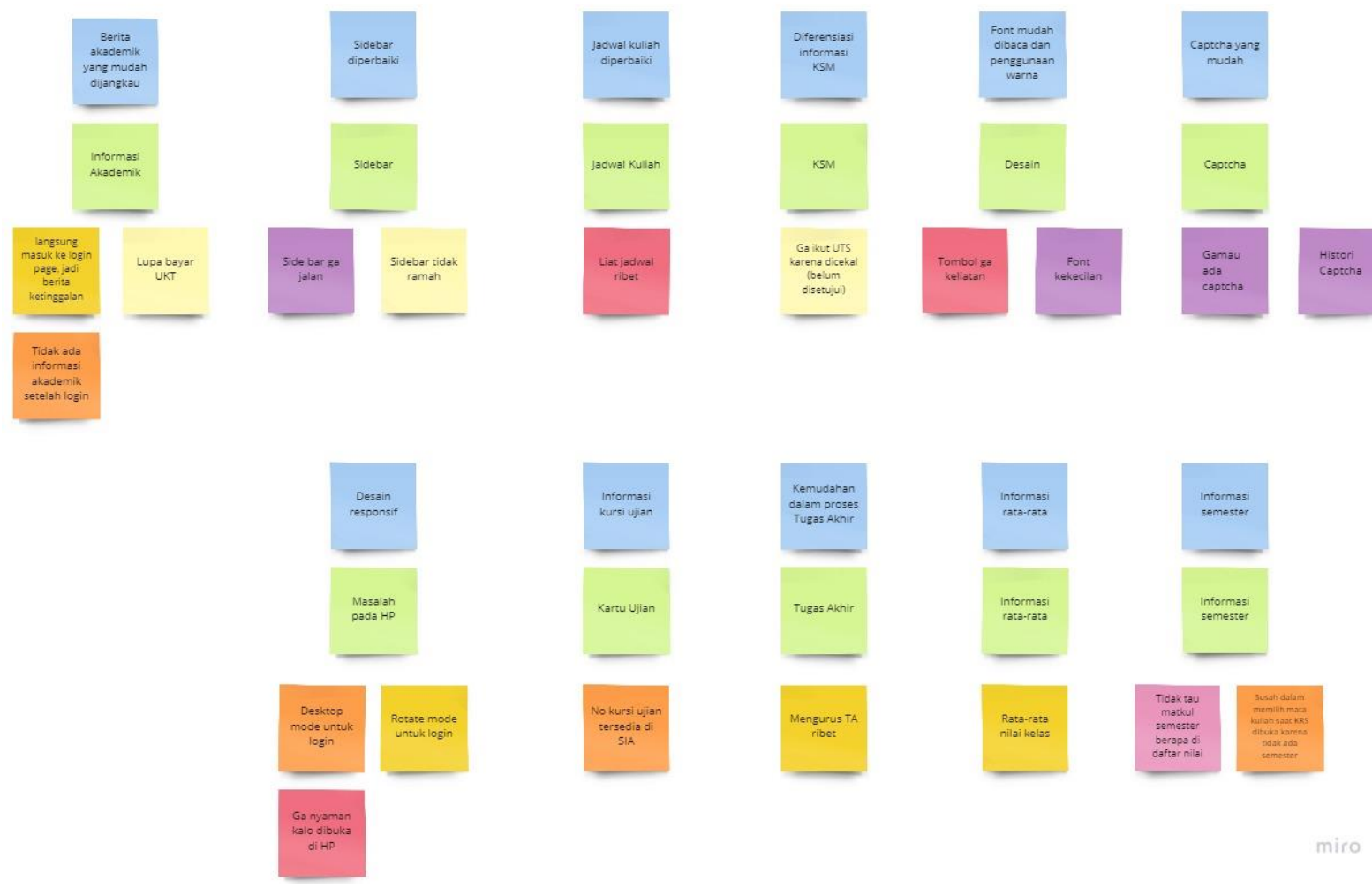

Gambar 1. Affinity Diagram

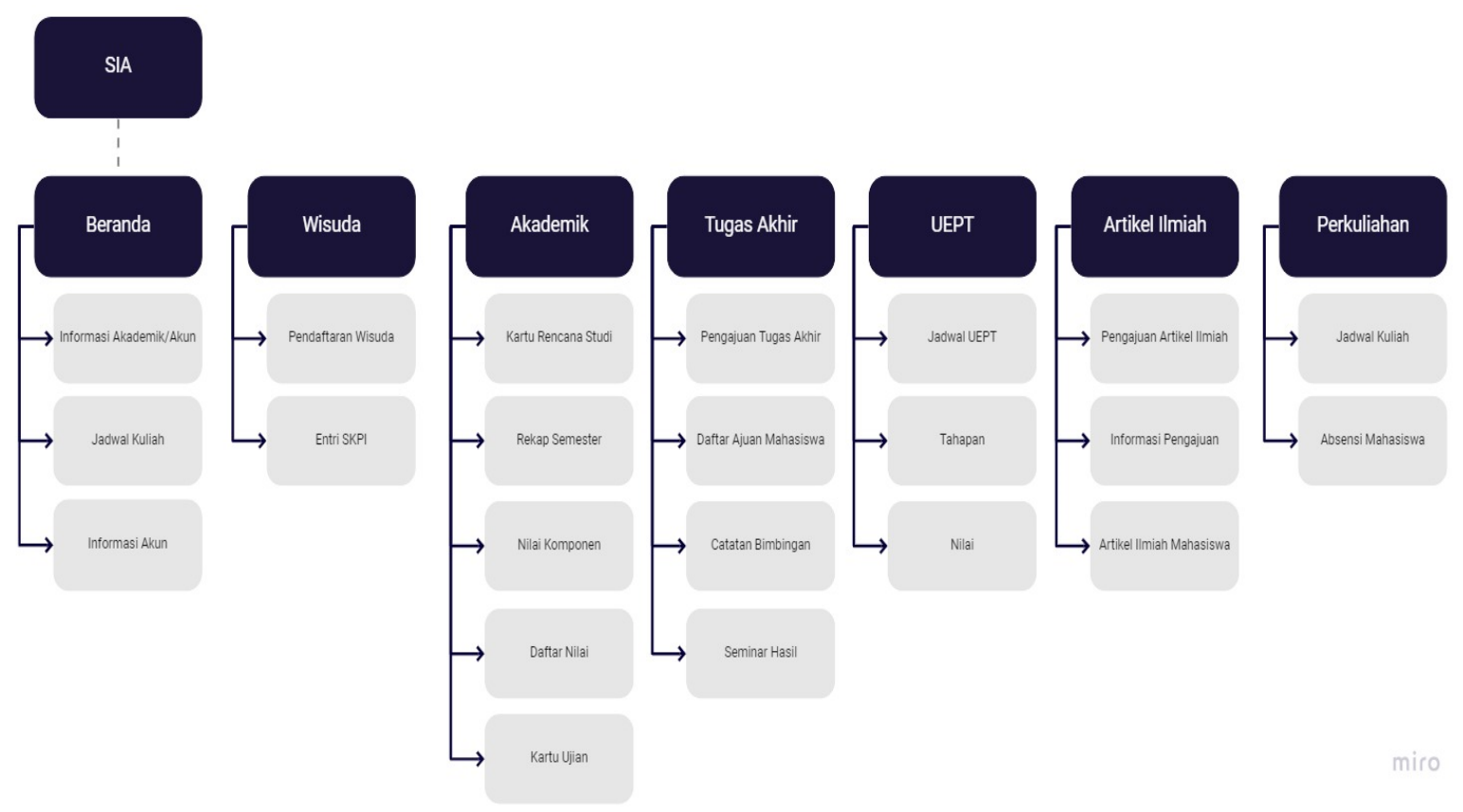

Gambar 2. Information Architecture 


\subsection{Ideate}

Pada tahapan ini penggambaran solusi dari berbagai ide yang telah didiskusikan [17]. Solusi ini digambarkan dengan menggunakan gambar mockup untuk memudahkan proses kedepannya. Gambar 3 merupakan beberapa hasil desain yang dihasilkan dari proses ideate ini.

\begin{tabular}{cl}
\multicolumn{1}{c}{ Tabel 1. Daftar kebutuhan pengguna } \\
\hline No & \multicolumn{1}{c}{ Kebutuhan pengguna } \\
\hline 1 & Informasi akademik yang lebih mudah dijangkau \\
2 & Sidebar yang ramah \\
3 & Jadwal kuliah yang mudah dijangkau \\
4 & Diferensiasi informasi pada Kartu Studi \\
5 & Mahasiswa \\
& tombol \\
6 & Captcha yang mudah namun tetap terjaga \\
7 & Responsif \\
8 & Penambahan Nomor Kursi Ujian \\
9 & Pengurusan Tugas Akhir yang mudah \\
10 & Informasi rata-rata nilai mata kuliah \\
11 & Penambahan informasi pada tabel \\
\hline
\end{tabular}

\subsection{Prototype}

Proses prototype ini merupakan proses mengimplementasikan ide yang sudah didapat. Tahapan ini menghasilkan prototype atau produk yang siap diuji, Gambar 4 merupakan hasil desain pertama dari SIA.

\subsection{Test}

Dalam pengujian ini digunakan 10 partisipan dimana 5 partisipan untuk mencari indikator kepada mahasiswa yang telah mengetahui dan membantu dalam perancangan desain ini dan 5 partisipan yang lain diantaranya 4 mahasiswa yang belum mengetahui dan 1 yang tidak tahu ada sistem ini.

Sebelum melakukan pengujian, digunakan usability testing dimana pertama kali dalam memulai pengujian yaitu membuat goals dan scenario. Kemudian mencari indikator waktu sebagai dasar dari pengujian. Pencarian indikator waktu ini dilakukan dengan melakukan uji coba kepada pengguna yang mengikuti perkembangan dari penelitian ini, sehingga ketika diuji kembali dengan pengguna lain mampu memberi hasil yang diharapkan.

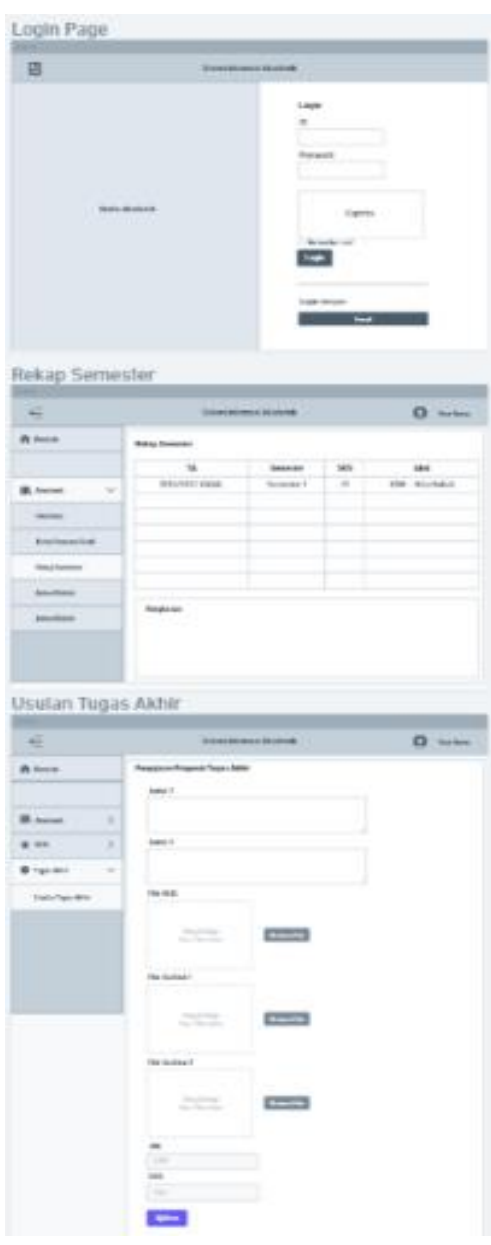

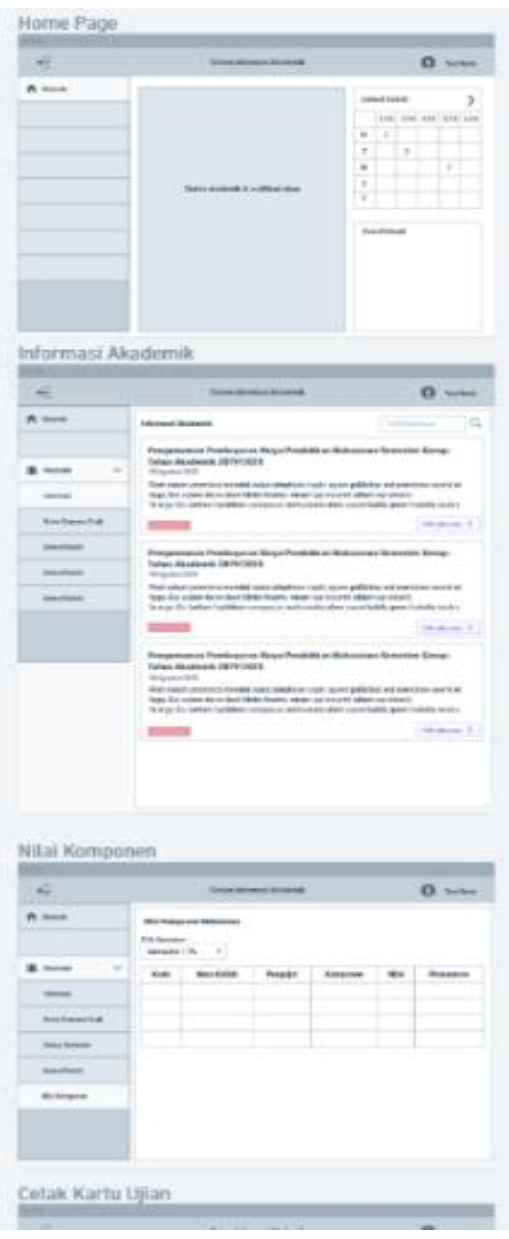

Gambar 3. Mockup

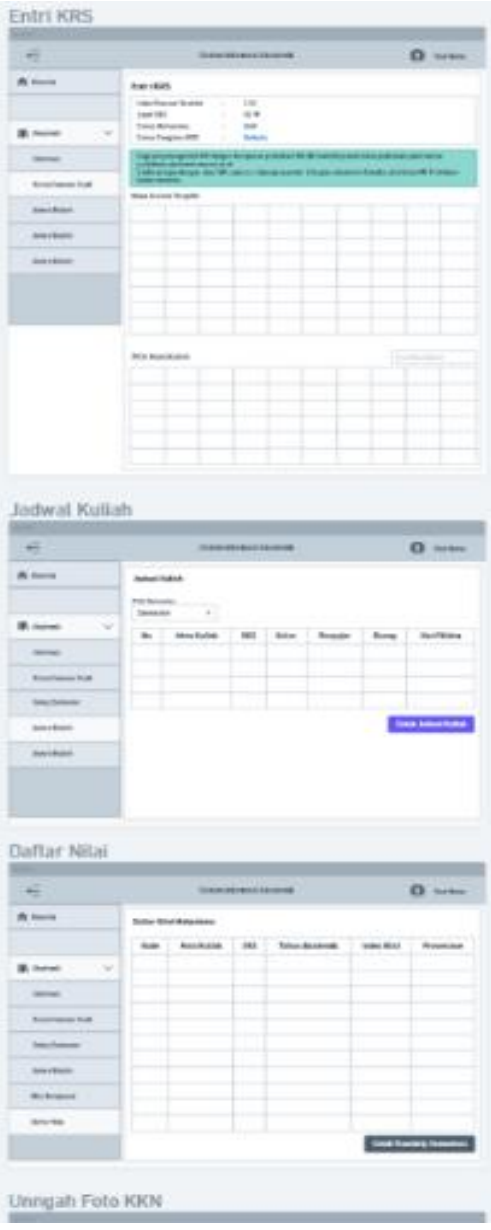



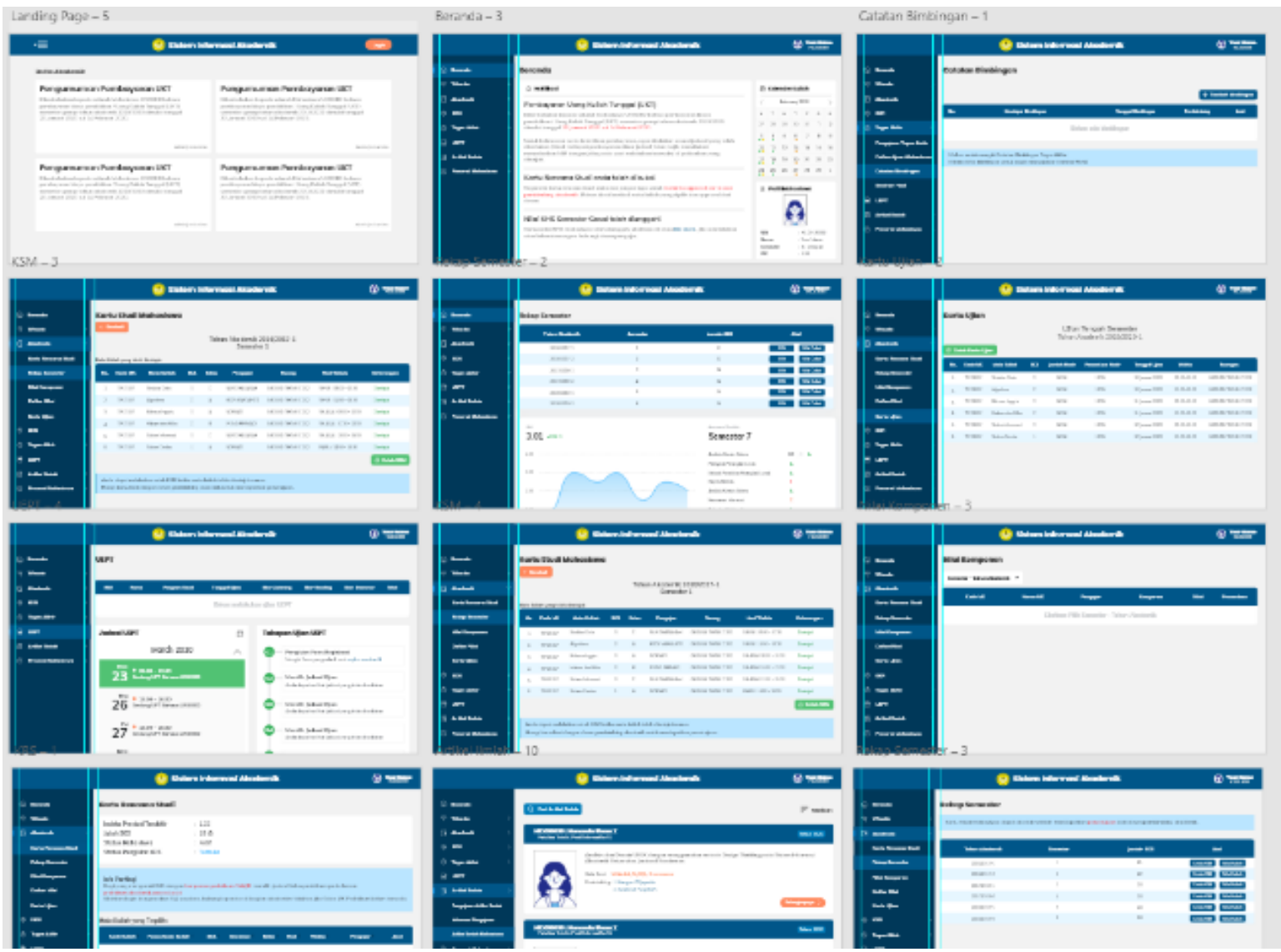

Gambar 4. Prototype

\section{Sistem Informasi Akademik}

Berita Akademik

\section{Pengumuman Pembayaran UKT}

Diberitahukan kepada seluruh Mahasiswa UNSOED bahwa pembayaran biaya pendidikan / Uang Kuliah Tunggal (UKT) semester genap tahun akademik 2019/2020 dimulai tanggal 20 Januari 2020 s. 14 Februari 2020.

\section{Pengumuman Pembayaran UKT}

Diberitahukan kepada seluruh Mahasiswa UNSOED bahwa pembayaran biaya pendidikan / Uang Kuliah Tunggal (UKT) semester genap tahun akademik 2019/2020 dimulai tanggal 20 Januari 2020 s.d 14 Februari 2020.

Penqumuman Pembayaran UKT

Gambar 5. Revisi Halaman Login

Setelah mendapatkan indikator kemudian dilakukan pengujian kepada mahasiswa sesuai dengan skenario dan goals yang telah di buat. Skenario dalam penelitian dibuat berdasarkan hal yang memiliki prioritas tinggi dan mengalami perubahan.

\section{Login}

Id User

your.name@mhs.ac.id|

Password

I'm not a robot

Login

Atau

\section{$\square$ Login dengan Email UNSOED}

1. Skenario Melihat Detail Jadwal Kuliah Berdasarkan hasil pengujian pada tabel 2, terdapat 3 partisipan yang memakan waktu yang lama pada saat login dan bercerita tentang pengalamannya saat menggunakan sistem yang sekarang jika hanya mengetik URL "akademik" langsung ke halaman 
login sehingga berita akademik tidak terbaca, kemudian layout dari informasi akademik itu sendiri. Hal tersebut sebagai dasar dan alasan untuk menggabungkan login dengan berita akademik seperti pada gambar 5 .

Tabel 2. Skenario Melihat Detail Jadwal Kuliah

\begin{tabular}{ccc}
\hline Penguji & Login & Memilih Card Jadwal \\
\hline 1 & $\ddots$ & \\
2 & $\ddots$ & \\
3 & $\ddots$ & \\
4 & $\ddots$ & \\
5 & & \\
\hline
\end{tabular}

\section{Skenario Menambah Catatan Bimbingan}

Tabel 3. Skenario Menambah Catatan Bimbingan

\begin{tabular}{cccc}
\hline Penguji & $\begin{array}{c}\text { Memilih sub } \\
\text { menu }\end{array}$ & $\begin{array}{c}\text { Memilih catatan } \\
\text { bimbingan }\end{array}$ & $\begin{array}{c}\text { Mengisi } \\
\text { form }\end{array}$ \\
\hline 1 & $\ddots$ & & \\
2 & $\ddots$ & 0 & \\
3 & $\ddots$ & 0 & \\
4 & $\ddots$ & 0 & \\
5 & 0 & 0 & \\
\hline
\end{tabular}

Berdasarkan hasil pengujian pada tabel 3, partisipan mampu menyelesaikan semua langkah dengan mudah pada skenario yang diberikan berdasarkan goals yang dicapai.

3. Skenario Pengajuan Seminar Hasil

Berdasarkan hasil pengujian pada tabel 4, partisipan mampu menyelesaikan semua langkah dengan tambahan gestur senyum yang menandakan kemudahan dalam menyelesaikan tugasnya.

\begin{tabular}{|c|c|c|c|c|}
\hline Penguji & $\begin{array}{c}\text { Memilih } \\
\text { sub menu }\end{array}$ & $\begin{array}{l}\text { Melihat } \\
\text { ruangan }\end{array}$ & $\begin{array}{c}\text { Mengisi } \\
\text { form }\end{array}$ & Ajukan \\
\hline 1 & 0 & 0 & 0 & 0 \\
\hline 2 & 0 & 0 & 0 & O \\
\hline 3 & 0 & 0 & 0 & 0 \\
\hline 4 & 0 & 0 & 0 & 0 \\
\hline 5 & 0 & 0 & 0 & 0 \\
\hline
\end{tabular}

\begin{tabular}{|c|c|c|c|c|}
\hline \multicolumn{5}{|c|}{ Tabel 5. Skenario Update Akun } \\
\hline Penguji & $\begin{array}{l}\text { Memilih } \\
\text { akun }\end{array}$ & $\begin{array}{l}\text { Mengisi } \\
\text { data diri }\end{array}$ & $\begin{array}{l}\text { Mengisi } \\
\text { domisili }\end{array}$ & $\begin{array}{c}\text { Memilih } \\
\text { tombol } \\
\text { update }\end{array}$ \\
\hline 1 & 0 & 0 & 0 & 0 \\
\hline 2 & 0 & 0 & - & 0 \\
\hline 3 & ○ & 0 & - & 0 \\
\hline 4 & 0 & 0 & - & O \\
\hline 5 & - & 0 & 0 & 0 \\
\hline
\end{tabular}

4. Skenario Update Akun

Berdasarkan hasil pengujian pada tabel 5, terdapat 1 partisipan yang memakan waktu cukup lama untuk mencari pengaturan akunnya. Karena hanya terjadi pada 1 partisipan, diputuskan untuk tidak merevisi desain.

5. Skenario Mencari Artikel Ilmiah Sejenis

\begin{tabular}{ccccc}
\multicolumn{5}{c}{ Tabel 6. Skenario Mencari Artikel Ilmiah Sejenis } \\
\hline Penguji & $\begin{array}{c}\text { Memilih } \\
\text { artikel } \\
\text { ilmiah }\end{array}$ & $\begin{array}{c}\text { Memilih } \\
\text { tombol } \\
\text { cari }\end{array}$ & $\begin{array}{c}\text { Memilih } \\
\text { kategori }\end{array}$ & $\begin{array}{c}\text { Memilih } \\
\text { tombol } \\
\text { cari }\end{array}$ \\
\hline 1 & & 0 & 0 & \\
2 & & 0 & 0 & \\
3 & & 0 & 0 & \\
4 & & 0 & 0 & \\
5 & & & & \\
\hline
\end{tabular}

Berdasarkan hasil pengujian pada tabel 6, partisipan mampu menyelesaikan semua langkah dengan mudah pada skenario yang diberikan berdasarkan goals yang dicapai.

6. Skenario Melihat Statistik dan Semester Terakhir

Tabel 7. Skenario Melihat Detail Jadwal Kuliah

\begin{tabular}{ccc}
\hline Penguji & $\begin{array}{c}\text { Memilih rekap } \\
\text { semester }\end{array}$ & $\begin{array}{c}\text { Memilih semester } \\
\text { terakhir }\end{array}$ \\
\hline 1 & 0 & \\
2 & 0 & \\
3 & 0 & \\
4 & 0 & \\
5 & 0 & \\
\hline
\end{tabular}

Berdasarkan hasil pengujian pada tabel 7, terdapat 1 partisipan yang cukup lama dalam memilih rekap semester. Sehingga, diputuskan untuk tidak merevisi pada halaman tersebut. Namun, karena terdapat 2 yang merasa cukup mudah pada halaman memilih semester terakhir yaitu pada grafiknya dan dibutuhkan untuk melakukan perubahan, sehingga statistik IPK dirubah menjadi sebuah tabel seperti pada gambar 6 .

7. Skenario Pengajuan Artikel Ilmiah

\begin{tabular}{ccccc}
\multicolumn{5}{c}{ Tabel 8. Skenario Update Akun } \\
\hline Penguji & $\begin{array}{c}\text { Mengisi } \\
\text { Judul }\end{array}$ & $\begin{array}{c}\text { Mengung } \\
\text { gah file }\end{array}$ & $\begin{array}{c}\text { Mengisi } \\
\text { kata } \\
\text { kunci }\end{array}$ & $\begin{array}{c}\text { Memilih } \\
\text { tombol } \\
\text { ajukan }\end{array}$ \\
\hline 1 & 0 & & & \\
2 & 0 & & 0 & \\
3 & 0 & & 0 & \\
4 & 0 & & 0 & \\
5 & 0 & & & \\
\hline
\end{tabular}


Hananda Ilham, dkk, Analysis And Design Of User Interface/User Experience With The Design Thinking ... 23

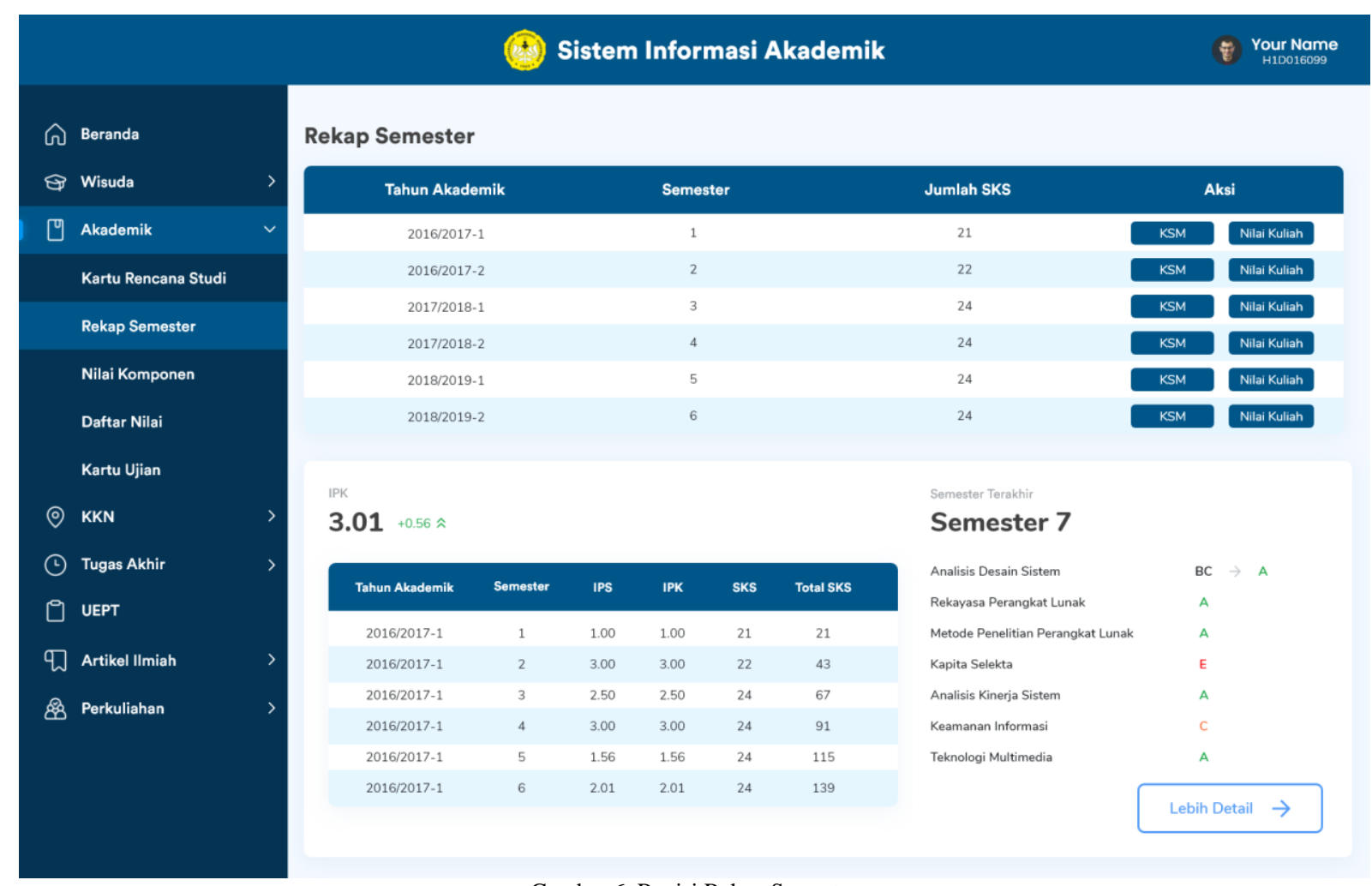

Gambar 6. Revisi Rekap Semester

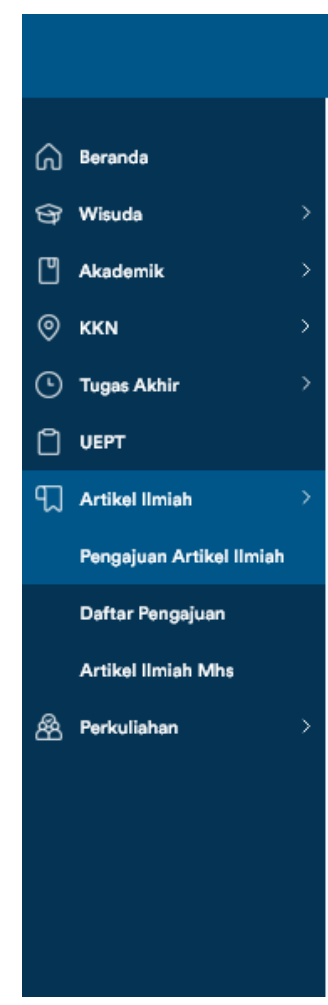

\section{Sistem Informasi Akademik}

Pengajuan Artikel IImiah

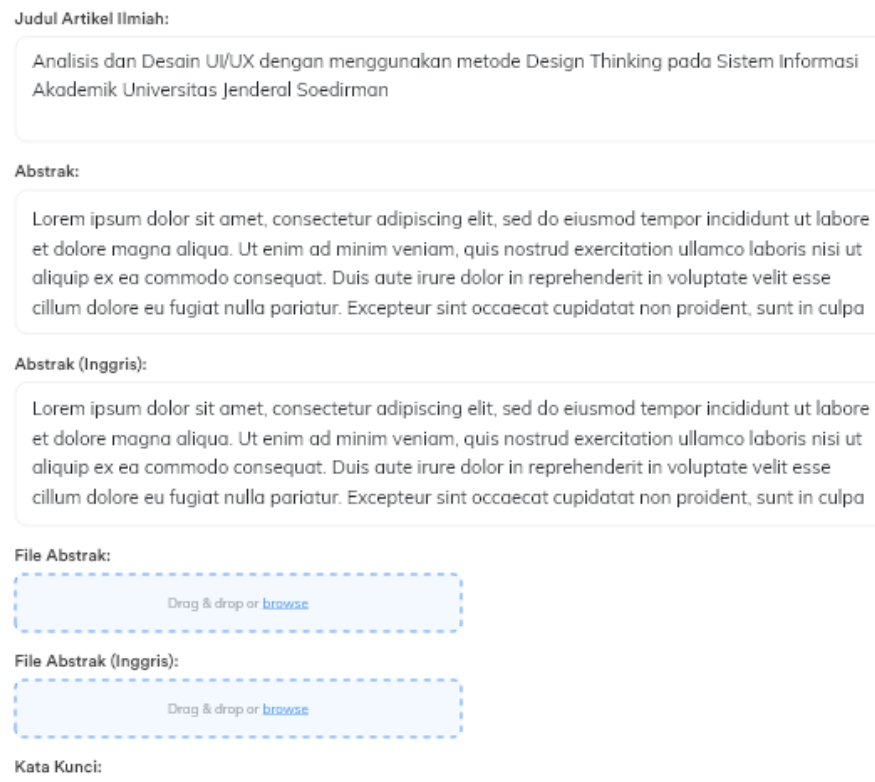

Lorem ipsum dolor sit amet, consectetur adipiscing elit, sed do eiusmod tempor incididunt ut labore et dolore magna aliqua. Ut enim ad minim veniam, quis nostrud exercitation ullamco laboris nisi ut aliquip ex ea commodo consequat. Duis aute irure dolor in reprehenderit in voluptate velit esse

Gambar 7. Revisi Pengajuan Artikel Ilmiah

Dari hasil pengujian pada tabel 8 , terdapat 2 partisipan yang mendapati ketidakmudahan dalam mengunggah file. Diputuskan untuk merevisi tampilan pada halaman pengajuan artikel ilmiah. Revisi ini diperlukan karena 2 dari 5 partisipan mengalami masalah yang mampu menghambat jalanya pengajuan dan mungkin bisa terjadi kesalahan. Setelah ditelusuri dari desain lama, ditemukan masalahnya yaitu pada perbedaan upload box dan tombol browse. Hal ini membingungkan pengguna, maka dari itu dilakukan desain ulang field 
ini yang akhirnya menjadi satu serta menambahkan background untuk membedakan form dengan latar.

8. Skenario Mencari Nomor Kursi Ujian

\begin{tabular}{ccc}
\multicolumn{3}{c}{ Tabel 9. Skenario Update Akun } \\
\hline Penguji & Login & $\begin{array}{c}\text { Memilih sub menu kartu } \\
\text { ujian }\end{array}$ \\
\hline 1 & & \\
2 & 0 & \\
3 & & \\
4 & & \\
5 & & \\
\hline
\end{tabular}

\begin{tabular}{|c|c|c|c|c|}
\hline Penguji & $\begin{array}{c}\text { Memilih } \\
\text { s KRS }\end{array}$ & $\begin{array}{c}\text { Memilih } \\
\text { mata } \\
\text { kuliah }\end{array}$ & $\begin{array}{c}\text { Memilih } \\
\text { rekap } \\
\text { semester }\end{array}$ & $\begin{array}{c}\text { Memilih } \\
\text { tombol } \\
\text { KSM } \\
\end{array}$ \\
\hline 1 & 0 & 0 & 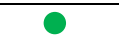 & 0 \\
\hline 2 & ○ & - & ○ & • \\
\hline 3 & - & - & 0 & 0 \\
\hline 4 & - & ○ & ○ & - \\
\hline 5 & $\bullet$ & 0 & $\bullet$ & $\bullet$ \\
\hline
\end{tabular}

Berdasarkan hasil pengujian pada tabel 9, terdapat 3 partisipan yang menyelesaikannya cukup lama. Sama seperti skenario sebelumnya halaman login diubah.
9. Skenario pada masa KRS-an

Berdasarkan hasil pengujian pada tabel 10, hanya terdapat 1 partisipan yang memakan waktu cukup lama dalam memilih sub menu rekap semester dan tombol KSM, sehingga diputuskan untuk tidak dilakukan revisi.

\subsection{Pengujian Iterasi Kedua}

Pada pengujian iterasi kedua ini bertujuan untuk memastikan bahwa revisi yang sudah dibuat mampu menjawab kebutuhan pengguna.

1. Skenario Melihat Detail Jadwal Kuliah

Berdasarkan hasil pengujian pada tabel 11, dapat disimpulkan bahwa setelah dilakukannya revisi mampu memberikan kemudahan yang lebih kepada pengguna, sehingga mampu menyelesaikan tugasnya berdasarkan goals yang ingin dicapai.

Tabel 11. Skenario Melihat Detail Jadwal Kuliah

\begin{tabular}{ccc} 
Penguji & Login & Memilih Card Jadwal \\
\hline 1 & & \\
2 & $\ddots$ & \\
3 & $\ddots$ & \\
4 & $\ddots$ & \\
5 & & \\
\hline
\end{tabular}

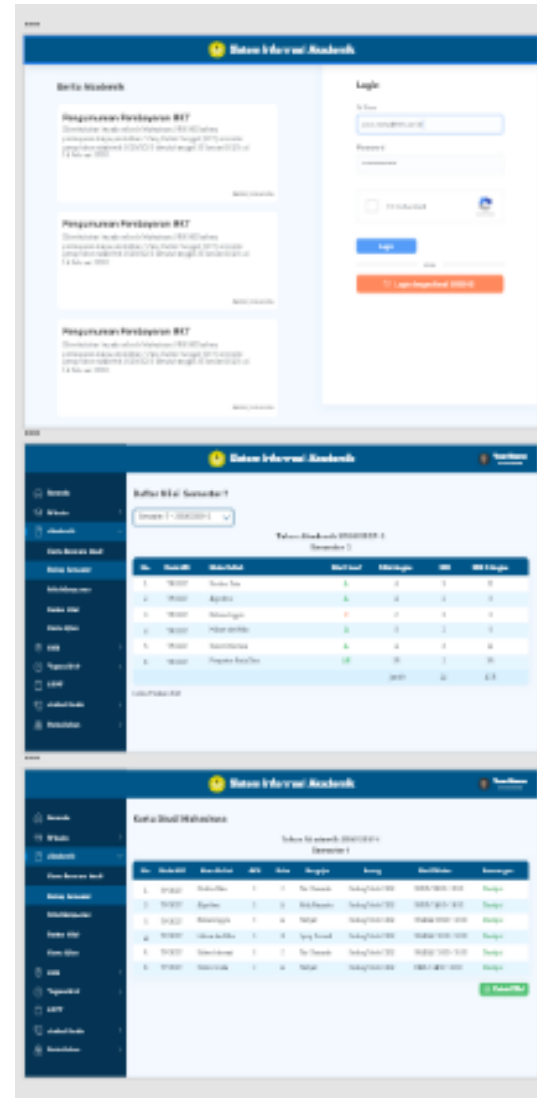

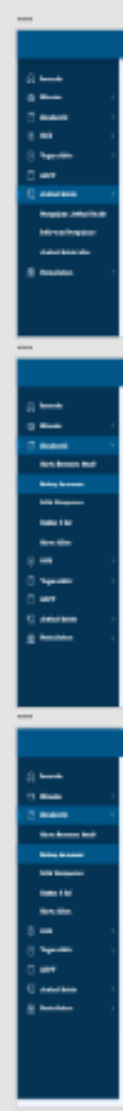

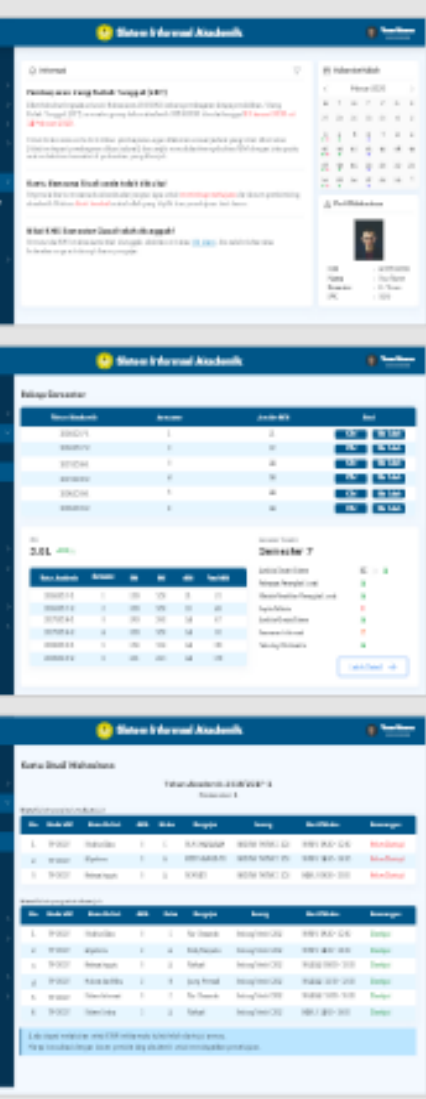

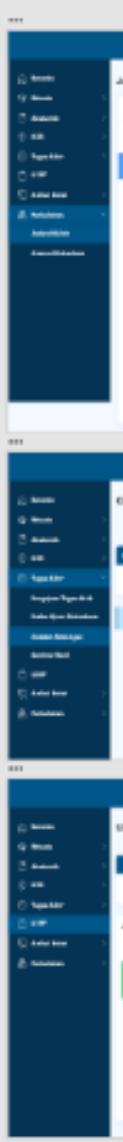

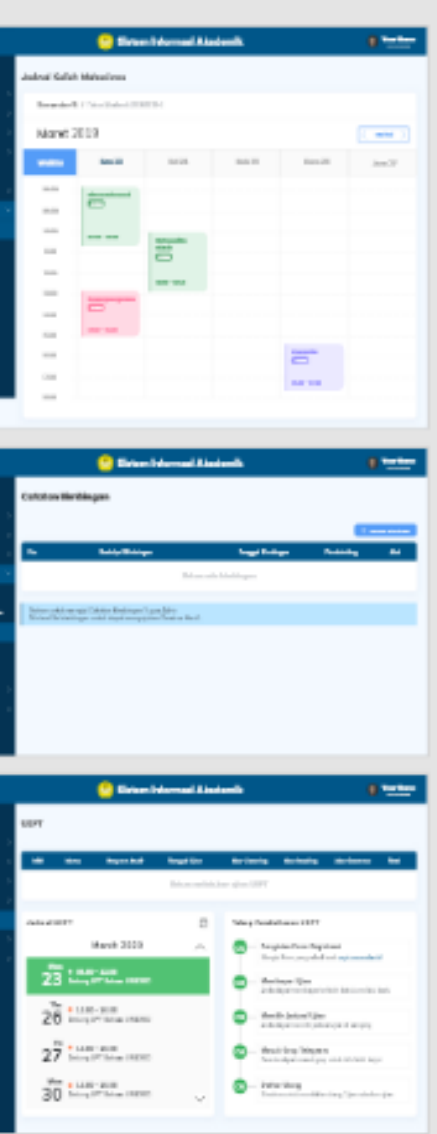

Gambar 8. Hasil Prototype Akhir 
2. Skenario Pengajuan Artikel Ilmiah

Berdasarkan hasil pengujian pada tabel 12, dapat disimpulkan bahwa hasil revisi mampu memperbaiki permasalahan yang didapat pada iterasi satu dan mencapai goals dengan mudah dan nyaman yang dapat dilihat dari gestur senyum yang diberikan.

Tabel 12. Skenario Pengajuan Artikel Ilmiah

\begin{tabular}{ccccc}
\hline Penguji & $\begin{array}{c}\text { Mengisi } \\
\text { Judul }\end{array}$ & $\begin{array}{c}\text { Mengung } \\
\text { gah file }\end{array}$ & $\begin{array}{c}\text { Mengisi } \\
\text { kata } \\
\text { kunci }\end{array}$ & $\begin{array}{c}\text { Memilih } \\
\text { tombol } \\
\text { ajukan }\end{array}$ \\
\hline 1 & 0 & 0 & & \\
2 & 0 & 0 & 0 & \\
3 & 0 & 0 & 0 & \\
4 & 0 & 0 & 0 & \\
5 & 0 & 0 & 0 & \\
\hline
\end{tabular}

3. Skenario Melihat Statistik dan Semester Terakhir

Tabel 13. Skenario Melihat Detail Jadwal Kuliah

\begin{tabular}{ccc}
\hline Penguji & $\begin{array}{c}\text { Memilih rekap } \\
\text { semester }\end{array}$ & $\begin{array}{c}\text { Memilih semester } \\
\text { terakhir }\end{array}$ \\
\hline 1 & & \\
2 & & \\
3 & & \\
4 & & \\
5 & 0 & \\
\hline
\end{tabular}

Berdasarkan hasil pengujian pada tabel 13, dapat disimpulkan bahwa hasil revisi mampu memperbaiki permasalahan yang didapat pada iterasi satu dan mencapai goals dengan mudah dan nyaman yang dapat dilihat dari gestur senyum yang diberikan.

\subsection{Hasil Akhir}

Setelah melewati berbagai tahapan yang ada pada Design Thinking, didapat hasil akhir prototype. Dari prototype pertama hingga akhir, terdapat perubahan-perubahan dasar seperti pada warna, penempatan button serta terdapat juga perubahan yang besar.

\section{KESIMPULAN}

Perancangan dan analisis User Interface (Antarmuka) dan User Experience (Pengalaman Pengguna) dapat menggunakan metode Design Thinking yang mampu menolong dalam memahami kebutuhan pengguna. Implementasi metode yang dimulai dari Empathize, Define, Ideate, Prototype dan Testing pada penelitian analisis dan perancangan desain UI/UX pada SIA Unsoed dirasa mampu membantu dalam menghasilkan desain prototype produk yang sesuai dengan kebutuhan mahasiswa. Hasil dari desain ini telah melewati proses pengujian secara langsung oleh mahasiswa dengan menggunakan usability testing.

\section{DAFTAR PUSTAKA}

[1] T. Brown and B. Katz, "Change by design," J. Prod. Innov. Manag., 2011, doi: 10.1111/j.1540-5885.2011.00806.x.

[2] S. D. Ali, "Design Thinking," School of Information Systems, 18-Dec-2018. [Online]. Available: https://sis.binus.ac.id/2017/12/18/designthinking-2/. [Accessed: 31-Oct-2020].

[3] H. Plattner, "An introduction to design thinking: process guide," Inst. Des. Stanford, 2013.

[4] R. Alrubail, "Teaching Empathy Through Design Thinking," Edutopia, 2015.

[5] R. F. Dam and T. Y. Siang, "Design Thinking: Getting Started with Empathy," Interaction Design Foundation, 2018.

[6] R. Dam and T. Siang, "Stage 2 in the Design Thinking Process: Define the Problem and Interpret the Results," Interaction Design Foundation, 2019.

[7] G. Ambrose and P. Harris, "Basics Design 08: Design Thinking," 2010.

[8] A. H. Fauzi and I. Sukoco, "Konsep Design Thinking pada Lembaga Bimbingan Belajar Smartnesia Educa," Organum J. Saintifik Manaj. dan Akunt., vol. 2, no. 1, pp. 37-45, 2019, doi: 10.35138/organum.v2i1.50.

[9] R. E. D. Ramadhana and A. Fatmawati, "Sistem Informasi Manajemen Keuangan Di Pondok Pesantren Adh-Dhuha Berbasis Web," Jurnal Teknik Informatika (JUTIF), vol. 1, no. 2, pp. 93-99, 2020, doi:10.20884/1.jutif.2020.1.2.20.

[10] J. R. Batmetan, "Model Desain Thinking Pada Perancangan Aplikasi Mobile Learning," 2018, doi: 10.31219/osf.io/xpzyr.

[11] J. Nielsen, "Why You Only Need to Test with 5 Users," Jakob Nielsens Alertbox, 2000.

[12] K. Dan and I. Banyumas, "APPLICATION OF MANAGEMENT PROJECTCOLLABORATION ON BANYUMAS," vol. 1, no. 1, pp. 13-18, 2020.

[13] H. M. Bratsberg, "Empathy Maps of the FourSight Preferences," Int. Cent. Stud. Creat., 2012.

[14] R. Dam and T. Siang, "Personas - A Simple Introduction," Interaction Design Foundation, 2019.

[15] R. Dam and T. Siang, "Affinity Diagrams Learn How to Cluster and Bundle Ideas and Facts | Interaction Design Foundation," Interaction Design Foundation, 2019.

[16] Booth UX, “Complete Beginner's Guide to Information Architecture | UX Booth," UX Booth. 2015. 
26 Jurnal Teknik Informatika (JUTIF), Vol. 2, No. 1, Juni 2021, hlm. 17-26

[17] N. F. Ardian and H. Werdhaningsih, "PENGGUNAAN DESIGN THINKING DALAM PENGEMBANGAN PRODUK KERAJINAN IKM (Studi Kasus: Sentra Kerajinan Patung Kayu, Subang)," $J$. Dimens. Seni Rupa dan Desain, vol. 15, no. 1, p. 1, 2019, doi: 10.25105/dim.v15i1.4193. 